\title{
A tetrapod swimming traceway from the Triassic of Winterswijk, the Netherlands
}

\author{
Anne S. Schulp ${ }^{1,2,3, *}$, Remco W. Bleeker ${ }^{3}$, Adam Haarhuis ${ }^{3}$, Edwin van Spronsen ${ }^{1}$, \\ Melanie A. D. During ${ }^{2,3}$, Gerard Goris $^{3}$, Pim Kaskes ${ }^{1,2}$, Yuri Matteman ${ }^{1}$, Wout Winkelhorst ${ }^{3}$ \\ \& Herman Winkelhorst ${ }^{3}$
}

1 Naturalis Biodiversity Center, P.0. Box 9517, 2300RA Leiden, the Netherlands

2 Faculty of Earth and Life Sciences, Vrije Universiteit Amsterdam, De Boelelaan 1085, 1081HV Amsterdam, the Netherlands

3 Werkgroep Muschelkalk Winterswijk / Geologisch toezichthouders, c/o Herman Winkelhorst, Molenstraat 14, 7122ZW Aalten, the Netherlands

* Corresponding author. Email: anne.schulp@naturalis.nl

Manuscript received: 1 February 2017, accepted: 3 July 2017

\section{Abstract}

We describe a tetrapod swimming traceway from the Middle Triassic Vossenveld Formation of the Netherlands. Forty-five individual traces, each consisting of two parallel claw drag marks, were followed over $9 \mathrm{~m}$ in a roughly east-west direction. The asymmetry of the traceway geometry indicates the trace maker negotiated a lateral current. The trace maker could not be identified, but the traces described here are markedly different from Dikoposichnus traces attributed to swimming nothosaurs.

Keywords:: Anisian, swimming traces, Triassic

\section{Introduction}

The Anisian strata of the Vossenveld Formation of Winterswijk, the Netherlands, have yielded a diverse and often well-preserved fossil vertebrate fauna, comprising both skeletal remains and ichnofossils (e.g. Voeten et al., 2015, and references therein).

The Vossenveld Formation (Middle Triassic; Lower Muschelkalk Member (RNMUL), Van Adrichem Boogaert \& Kouwe, 19931997) is exposed in a quarry complex east of Winterswijk, near the Dutch-German border. Hagdorn \& Simon (2010) consider the exposed strata to be of Bithynian age.

Remarkably, the fossil tetrapod record from the Winterswijk quarry consists of skeletal remains of marine animals, and trackways of terrestrial animals, a scenario explained in Klein \& Sichelschmidt (2014) by 'carcasses of marine vertebrates [being] brought in by the tide [and] terrestrial vertebrates ... scavenging on the marine vertebrate bodies, [which would] explain the incompleteness and disarticulation pattern observed in many fossilized skeletons'. In this short contribution, we describe a large tetrapod swimming traceway from the Vossenveld Formation, comprising some two dozen claw mark pairs. The tetra- pod walking trackway record of the Vossenveld Formation has been described in much detail (e.g. Faber, 1958; Demathieu \& Oosterink, 1988; 0osterink et al., 2003; 0osterink \& Winkelhorst, 2013: 64). Swimming traces made by fish have been reported from the Winterswijk Triassic, too, but only as unspecified 'Undichna isp.' (e.g. Diedrich, 2002: 201; not illustrated; Oosterink \& Winkelhorst, 2013: 64). However, we are not aware of any previous work describing tetrapod swimming traceways from this quarry in any detail, and we therefore consider a brief description warranted.

We here follow Thomson \& Droser (2015) by referring to a series of swim marks as a traceway instead of trackway, as the individual swimming traces convey hardly any anatomical information on the foot morphology of the trace-maker, and one could argue they thus hardly qualify as a recognisable 'trackway' sensu stricto.

\section{Materials and methods}

The main exposures of the Vossenveld Formation are on the property of the Sibelco Winterswijk quarry, east of the city 


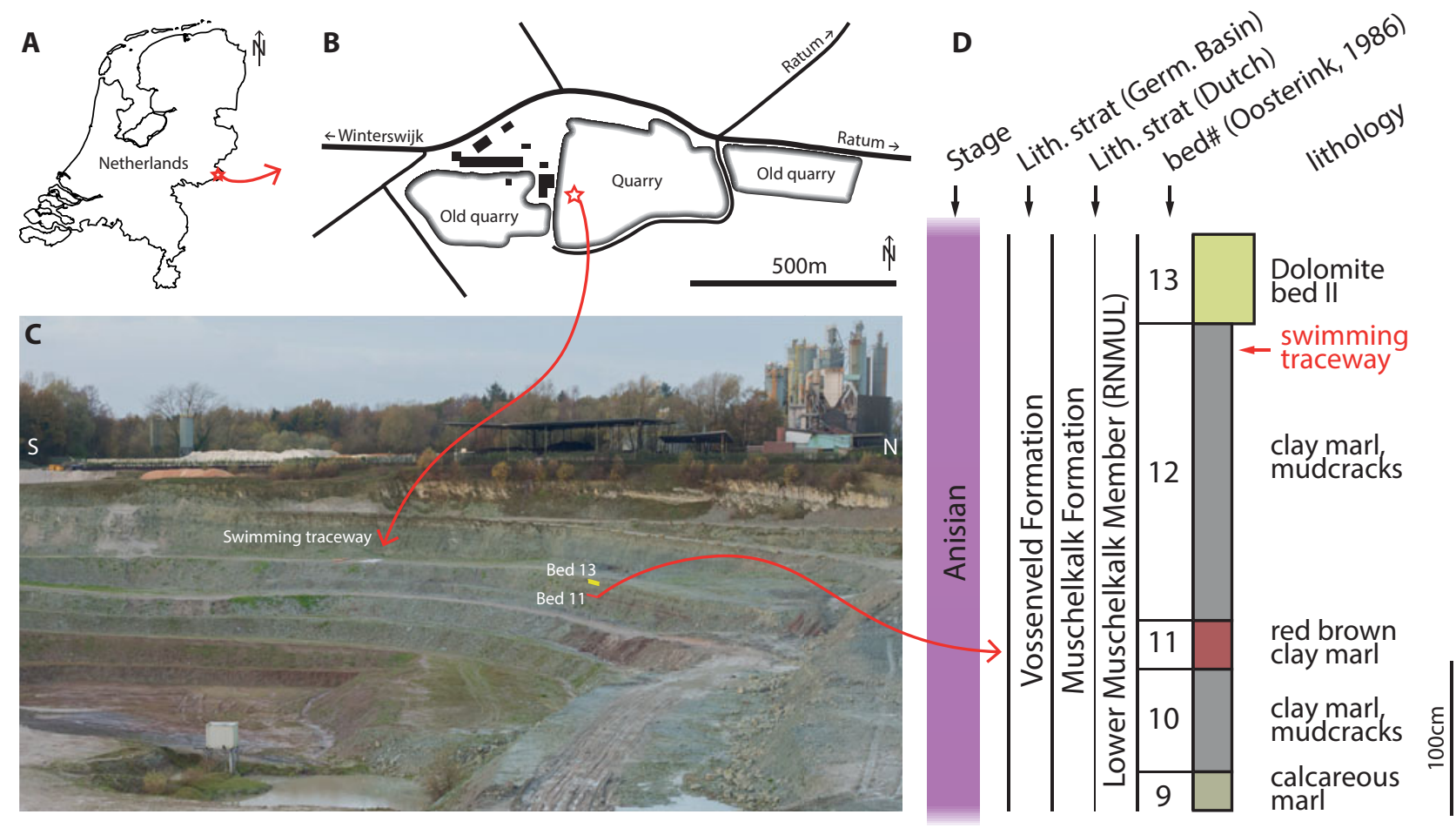

Fig. 1. ( $A, B)$ Location map of the quarry complex. The swimming traceway described here comes from the western side of the middle (active) quarry; indicated by the star in $(B)$ and the red arrow to $(C)$, photo taken from the road east of the active quarry looking west; the conspicuous beds 11 and 13 are indicated. (D) Lithology of the section studied here, with the bed numbering from Oosterink (1986) (which has become the de facto standard in the quarry among the fossil collector community) and the traceway level indicated.

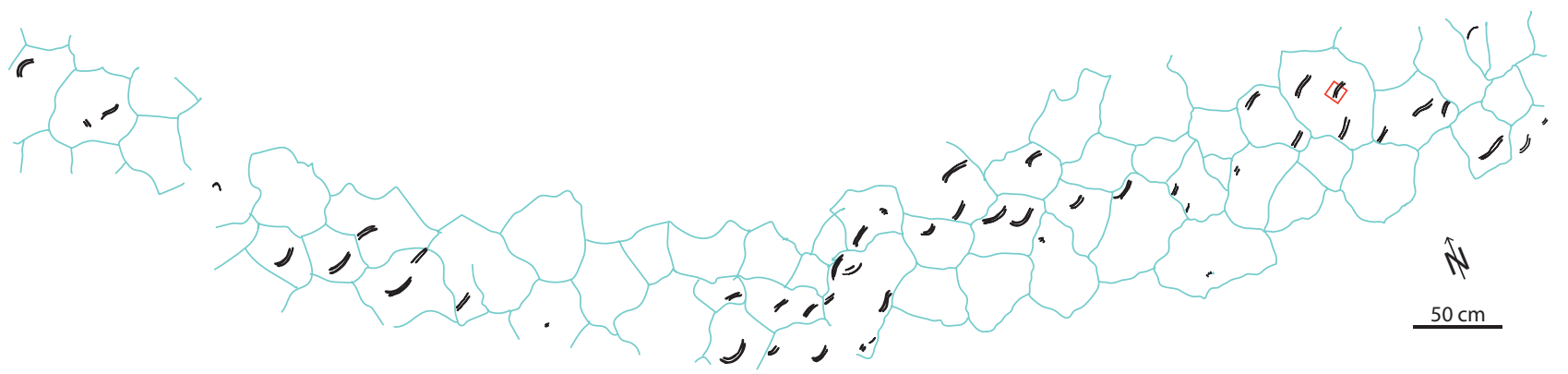

Fig. 2. Tracing of the tetrapod swimming traceway. Scale bar equals $50 \mathrm{~cm}$. Red square: traceway in Figure 3 and supplementary online information (https://doi.org/10.1017/njg.2017.13).

of Winterswijk (Fig. 1). The traces described here were discovered in this quarry on 12 September 2015 by R.W.B.; most of the eastern half of the area described here was uncovered during that day, after which the national natural history museum of the Netherlands, Naturalis Biodiversity Center in Leiden, was informed. The quarry management kindly kept operations at the fossil locality on hold pending further excavation, which was performed on 14 November 2015, by all the authors.

That day, the traceway was further followed to the west, tracings were made using transparent plastic sheets, a selection of traces was documented in detail using photogrammetry, and a selection of best-preserved and most representative traces was excavated. The entire traceway was subsequently photographed from the transparent plastic sheets on a $50 \times 50 \mathrm{~cm}$ grid, and digitised from those $50 \times 50 \mathrm{~cm}$ tiles using Adobe Illustrator (Figs 2, 3).

The stratigraphic position of the track-bearing layer is some $20 \mathrm{~cm}$ below the top of 'Bed 12' (Fig. 1), following the lithostratigraphic subdivision of 0osterink (1986), which is $2 \mathrm{~cm}$ below the level which yielded abundant jellyfish impressions, as described in 0osterink \& Winkelhorst (2013). Tetrapod tracks reported so far from Bed 12 include Rhynchosauroides peabodyi and Procolophonichnium haarmuelensis (see 0osterink \& Winkelhorst, 2013). The sedimentological setting has been interpreted as algal laminates, deposited in a sabkha setting. 


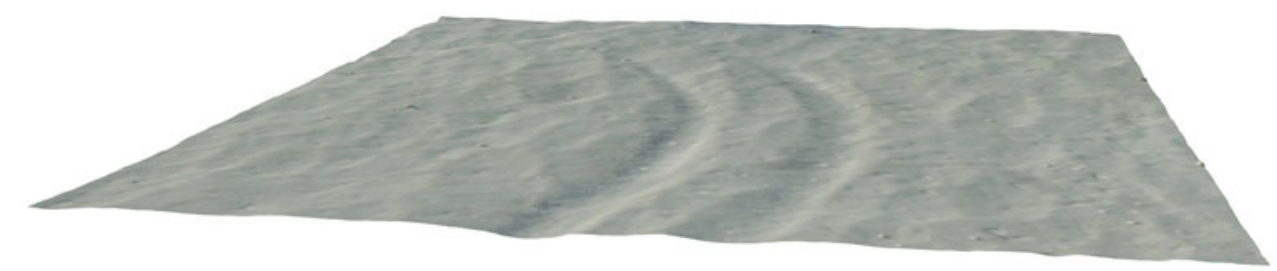

Fig. 3. Cross-section of the swimming traceway (outlined in red in Fig. 2) based on photogrammetry. A 3D-.pdf model is available as supplementary online information (https://doi.org/10.1017/njg.2017.13).

\section{Description}

The specimen is registered as RGM.792288 (institutional abbreviation: RGM: Naturalis Biodiversity Center, Leiden, the Netherlands); it consists of ten consecutive slabs with the wellpreserved, representative mid-section of the traceway, along with three transparent plastic sheets with tracings made of the entire traceway as exposed in November 2015.

The traceway as documented consists of 45 well-recognisable individual traces (Fig. 2), which could be followed along a somewhat curved path for about $9 \mathrm{~m}$. Each individual trace is almost invariably preserved as a set of two curved or occasionally slightly sigmoid parallel scratches.

We could not identify a marked difference in morphology or position/orientation or traceway width between consecutive sets of traces, and therefore suggest that the water depth was such that the trace maker was sufficiently buoyant, but with the centre of buoyancy not fully coinciding with the centre of mass, to have the pes or the manus scratch the substrate if ever so slightly.

A single out-of-sequence scratch mark with a different curvature and orientation could well represent an instant where the other autopodial touched the substrate: this scratch occurs exactly at the point where the trace maker made a turn, so the roll associated with taking this turn could well account for that.

In swimming traces, where swimming speed, water current, hydrodynamic drag, intended heading and centre of mass vs centre of buoyancy all have an impact on the traceway geometry, analysing the 'stride' length is of limited use, but traceway width can help narrow down the identity of the track maker. Assuming that the traces are left by either the pes or the manus, the 'stride' length at the most regular, continuous traceway section to the east of the curve ranges between 21 and $29 \mathrm{~cm}$. There, the traceway is about $32 \mathrm{~cm}$ wide, in other words, each of the limbs of the trace maker must have extended up to more than $16 \mathrm{~cm}$ from the sagittal plane.

The traceway is oriented in a general east-west direction. Extramorphological features indicative of the direction in which the impressions were formed could not be discerned. In most cases, the position and geometry of mud ridges in swimming traces provides an unambiguous indication of the direction in which the scratch was made (cf. Milner \& Lockley, 2016). Here, however, the substrate conditions were apparently less conducive to the build-up of sediment mounds, and the tips of the slender claws were impressed in such a gentle way (i.e. touched, slid and gently taken off), that we cannot confidently reconstruct the direction of movement based on mud ridge morphology. No indication of drag marks made by 'webbing' between the two claws could be discerned, nor did we recognise any suggestion of a tail drag trace. The traces are generally a few mm deep at most; distance between the two scratch marks amounts to about $1.5 \mathrm{~cm}$ in most places.

\section{Discussion}

\section{Cross-current}

The marked left-right asymmetry observed in this traceway is particularly interesting. Ezquerra et al. (2007) describe a similar asymmetry (though of a different scale) in a 'swimming dinosaur trackway' from the Early Cretaceous of Spain, and they hypothesise the asymmetry to have been caused by a '[lateral] water current' (Ezquerra et al., 2007: 509). In the traceway described here, the traces on the north side generally are more elongate and straight, and the southern counterparts display a much more pronounced curvature. This, too, can well be explained by the fact that the trace maker negotiated a gentle current at an angle to the intended direction of movement.

\section{Identification of the trace maker}

The process of the making and initial preservation of swimming traces, all the way to the eventual appearance of the resulting ichnofossils, involves a staggering number of variables. This includes not only body and appendicular morphology and swimming behaviour, but also factors such as water depth, substrate composition and substrate consistency, current direction, subsequent bioturbation, and diagenesis. Swimming traces can vary from almost fully recognisable 'footprints' (e.g., the 'swimming' tracks described by Müller, 1955 or McAllister, 1989), to more elongate striations, such as some of the hippopotamus traces described by Bennett et al. (2014). The amount of recognisable morphological information contained in a swimming trace 
is commonly far less than can be distilled from a detailed, 'elite' walking track, leaving the identification of the trace maker rather challenging. Whyte \& Romano (2001) erected the tetrapod swimming trace ichnotaxon Characichnos which they diagnosed as 'Two to four elongate, parallel ... grooves which may be straight, gently curved or slightly sinuous' (p. 232); their diagnosis is sufficiently broadly phrased that we may consider the present traceway cf. Characichnos, too. However, identifying, or at least narrowing down the number of, potential trace makers proves much more challenging. Both the body fossil record of larger (i.e. conceivably able to leave swimming traces at least $32 \mathrm{~cm}$ wide) tetrapods and track makers from the ichnofossil walking trackway record should be considered here, taking the aforementioned remark by Klein \& Sichelschmidt (2014) to heart.

Much descriptive work has been done in recent years on the tetrapod fossil record of the Winterswijk Triassic. From the faunal list as presented by 0osterink \& Winkelhorst (2013), most candidates can be readily omitted from consideration because of their small size. Also, the most recent additions to the tetrapod faunal list, Palatodonta bleekeri Neenan et al. (2013) and Pararcus diepenbroeki Klein \& Scheyer (2014), can be omitted from consideration for the same reason. Voeten et al. (2015) discuss larger-sized Eusauropterygian occurrences from the Vossenveld Formation with nothosaurian and cymatosaurian affinity. In terms of size, Nothosaurus should certainly be evaluated as a potential trace maker; the traceway morphology reported here, however, is decidedly different from the ichnotaxon Dikoposichnus luopingensis attributed to foraging Nothosaurus by Zhang et al. (2014). All of the traceways preserving left and right traces in Dikoposichnus are symmetrically paired, i.e. the animal propelled itself in a symmetric, 'rowing' (hence the name, dikopos, meaning two-oared) fashion. The asymmetric, alternating gait seen in the traceway described here then allows Dikoposichnus, and thus - if the attribution holds true - Nothosaurus, to be omitted from consideration, too. Both traceway width and the alternating gait leave the maker of the (rather common) Rhynchosauroides peabody tracks a likely candidate; compare figure 56 in 0osterink (1986) for dimensions, correlating favourably with the observed traceway width described here, and similarly the traceway impressions are compatible with the slender claws as seen in elite Rhynchosauroides trackways.

\section{Substrate conditions}

Swimming traces can differ considerably in appearance dependent on depth and buoyancy of the trace maker, as exemplified in the swimming hippopotamus tracks described in Bennett et al. (2014) - there, the morphology changes from deep, recognisable tracks to long parallel grooves imprinted by the almost fully buoyant animal. Similarly, Diedrich (2002) discussed the changing appearance of Rhynchosauroides tracks from dry to fully waterlogged substrate (Diedrich, 2002: fig 5A). If the traceways described in the present contribution were indeed left behind by the maker of Rhynchosauroides tracks, we could then add them on the far right side in figure $5 \mathrm{~A}$ of Diedrich (2002). The fact that the traceways we describe here all display two claw imprints, or very occasionally only one, is interesting. Crocodile swim tracks as described by Vila et al. (2014) show two, three or, occasionally, four parallel scratch marks attesting to roll; along similar lines one would expect additional claws of the trace maker discussed here to occasionally touch the substrate, too - however, we found no such indication. This might well be explained by the combination of the claw morphology of the Rhynchosauroides track maker, and indicate the traceway was produced by the animal swimming in relatively quiet water conditions, experiencing hardly any roll or pitch and limited yaw.

\section{Swim track occurrences}

Thomson \& Droser (2015) note the 'anomalously high' number of swim track occurrences in the Lower Triassic worldwide, which they link to the reduced intensity of bioturbation as a result of the delayed biotic recovery after the end-Permian mass extinction (Chen \& Benton, 2012), and the increased preservation potential of the semi-consolidated substrate due to lack of biogenic mixing. The exact stratigraphic age of Bed 12 has not yet been firmly established, but the Bithynian (Anisian) age of the Winterswijk Triassic (Hagdorn \& Simon, 2010), and the fact that many layers (e.g. 'Bed 10', Oosterink, 1986) are bioturbated, places this occurrence well above and beyond the earlier stages of biotic recovery as considered by Thomson \& Droser (2015).

\section{Outlook}

With all the emphasis in previous work on walking trackways, the swimming traceways from the Winterswijkse Steengroeve so far appear to have gone almost unnoticed. We hope this contribution will spark more interest in these particular trace fossils, which we hope will result in more fossils being recognised, recovered and described in the near future.

\section{Acknowledgements}

We would like to thank Gerard ten Dolle of the Winterswijkse Steengroeve / Sibelco for hospitality and support, the Journal's associate editor Geert-Jan Vis, reviewer Spencer Lucas and an anonymous reviewer for helpful comments on an earlier version of the manuscript.

\section{Supplementary material}

Supplementary material is available online at https://doi.org/ 10.1017/njg.2017.13. 


\section{References}

Bennett, M.R., Morse, S.A. \& Falkingham, P.L., 2014. Tracks made by swimming Hippopotami: an example from Koobi Fora (Turkana Basin, Kenya). Palaeogeography, Palaeoclimatology, Palaeoecology 409: 9-23.

Chen, Z.-Q. \& Benton, M.J., 2012. The timing and pattern of biotic recovery following the end-Permian mass extinction. Nature Geoscience 5: 375-383.

Demathieu, G.R. \& Oosterink, H.W., 1988. New discoveries of ichnofossils from the Middle Triassic of Winterswijk (the Netherlands). Netherlands Journal of Geosciences 67: 3-17.

Diedrich, C., 2002. Vertebrate track bed stratigraphy at new megatracksites in the Upper Wellenkalk Member and Orbicularis Member (Muschelkalk, Middle Triassic) in carbonate tidal flat environments of the western Germanic Basin. Palaeogeography, Palaeoclimatology, Palaeoecology 183: 185-208.

Ezquerra, R., Doublet, S., Costeur, L., Galton, P.M. \& Pérez-Lorente, F., 2007. Were non-avian theropod dinosaurs able to swim? Supportive evidence from an Early Cretaceous trackway, Cameros Basin (La Rioja, Spain). Geology 35: 507-510.

Faber, F.J., 1958. Fossiele voetstappen in de Muschelkalk van Winterswijk. Geologie en Mijnbouw 20: 317-321.

Hagdorn, H. \& Simon, Th., 2010. Vossenveld-Formation. In: Litholex (Lithostratigraphische Einheiten Deutschlands, Online-Datenbank). Record No. 45. Hannover: BGR. Available at www.bgr.bund.de/litholex, last accessed on 1 February 2017.

Klein, N. \& Scheyer, T.M., 2014. A new placodont sauropterygian from the Middle Triassic of the Netherlands. Acta Palaeontologica Polonica 59: 887-902.

Klein, N. \& Sichelschmidt, 0.J., 2014. Remarkable dorsal ribs with distinct uncinate processes from the early Anisian of the Germanic Basin (Winterswijk, The Netherlands). Neues Jahrbuch für Geologie und Paläontologie. Abhandlungen 271: 307-314.

McAllister, J.A., 1989. Subaqueous vertebrate footmarks from the Upper Dakota Formation (Cretaceous) of Kansas, U.S.A. Occasional papers of the Museum of Natural History, The University of Kansas, Lawrence, Kansas 127: 1-22.

Milner, A.R.C. \& Lockley, M.G., 2016. Dinosaur swim track assemblages: characteristics, contexts, and ichnofacies implications. In: Falkingham, P.L., Marty,
D. \& Richter, A.: Dinosaur tracks - the next steps. Indiana University Press (Bloomington \& Indianapolis): 151-180.

Müller, A.H., 1955. Ein kombinierte Lauf- und Schwimmfährte von Korynichnium aus dem Oberrotliegenden von Tambach (Thüringen). Geologie 4: 490-496.

Neenan, J.M., Klein, N. \& Scheyer, T.M., 2013. European origin of placodont marine reptiles and the evolution of crushing dentition in Placodontia. Nature Communications 4:1621. doi: 10.1038/ncomms2633.

Oosterink, H.W., 1986. Winterswijk, geologie deel II. De Trias-periode (geologie, mineralen en fossielen). Wetenschappelijke Mededelingen Koninklijke Nederlandse Natuurhistorische Vereniging 178: 1-120.

Oosterink, H.W. \& Winkelhorst, H., 2013. Probable remains of jellyfish (Cnidaria, Scyphozoa) from the lower Middle Triassic (Anisian) of Winterswijk, eastern Netherlands. Netherlands Journal of Geosciences / Geologie en Mijnbouw 92: 61-67.

Oosterink, H.W., Berkelder, W., de Jong, Ch., Lankamp, J. \& Winkelhorst, H., 2003. Sauriërs uit de Onder-Muschelkalk van Winterswijk. Staringia 11. Nederlandse Geologische Vereniging (Winterswijk,): 146 pp.

Thomson, T.J. \& Droser, M.L., 2015. Swimming reptiles make their mark in the Early Triassic: delayed ecologic recovery increased the preservation potential of vertebrate swim tracks. Geology 43: 215-218.

Van Adrichem Boogaert, H.A. \& Kouwe, W.F.P., 1993-1997. Upper Germanic Trias Group RN. In: Stratigraphic nomenclature of the Netherlands. Available at www.dinoloket.nl, last accessed May 2017.

Vila, B., Castanera, D., Marmi, J., Canudo, J.I. \& Galobart, À., 2014. Crocodile swim tracks from the latest Cretaceous of Europe. Lethaia 14: 256-266.

Voeten, D.F.A.E., Sander, P.M. \& Klein, N., 2015. Skeletal material from larger Eusauropterygia (Reptilia: Eosauropterygia) with nothosaurian and cymatosaurian affinities from the Lower Muschelkalk of Winterswijk, The Netherlands. Paläontologische Zeitschrift 89: 943. doi: 10.1007/s12542-014-0250-4.

Whyte, M.A. \& Romano, M., 2001. A dinosaur ichnocoenosis from the Middle Jurassic of Yorkshire, UK. Ichnos, 8: 223-234.

Zhang, Q., Wen, W., Hu, S., Benton, M.J., Zhou, C., Xie, T., Lü, T., Huang, J., Choo, B., Chen, Z.-Q., Liu, J. \& Zhang, Q., 2014. Nothosaur foraging tracks from the Middle Triassic of southwestern China. Nature Communications 5: 3973. doi: $10.1038 /$ ncomms4973. 